International Journal of Business Management and Economic Review

Vol. 4, No. 02; 2021

ISSN: 2581-4664

\title{
THE ROLE OF PERCEIVED UTILITARIAN VALUE AND STUDENT SATISFACTION IN MEDIATING THE EFFECT OF SERVICE QUALITY AND IMAGE TOWARDS LOYALTY AT UNIVERSITIESIN BANDA ACEH
}

\author{
*Nova Maulida, Jasman J Makruf and Syafruddin Chan \\ Department of Management, Universitas Syiah Kuala, Indonesia \\ http://doi.org/10.35409/IJBMER.2021.3245
}

\begin{abstract}
This study intends to examine the Role of Perceived Utilitarian Value and Student Satisfaction in Mediating the Influence of Service Quality (Servqual) and University Image on Loyalty at Universities in Banda Aceh city, Indonesia. This research was conducted on students of the Muhammadiyah University, SerambiMekkah University, and the Getsempena National Education and Teaching College, with a population of 1916 people. The sampling technique used is the Probability Sampling Technique. While the sampling method used was stratified random sampling to obtain a sample of 170 students. Data were analyzed using Structural Equation Modeling (SEM) with the help of Amos software. The results of the research found that all hypotheses proven in this research were accepted. This means that student loyalty in private university institutions in Aceh does have a determinant variable Servqual, University Image, Perceived Utilitarian Value, Customer Satisfaction, both of which affect loyalty directly or indirectly. The novelty of the research lies in the research model that results from the integration of previous causality theories and on new objects. Further researchers are expected to contribute by adding other variables such as student competence and religiosity.
\end{abstract}

Keyword:Perceived Utilitarian Value, Student Satisfaction, Servqual, Image, Loyalty.

\section{INTRODUCTION}

Loyalty is an important factor for the success of any business, including university. The efficiency resulting from increased loyalty to students, alumni, and other stakeholders causes not only an increase in income at universities such as income obtained from tuition fees from students, donations from alumni and other income obtained from stakeholders, both from the form of cooperation and grants but also provide some synergy for enrollments through word of mouth recommendation activities. However, this has not fully occurred in universities in Banda Aceh city, Indonesia, where students, alumni, and stakeholders have not been fully loyal to the university institutions.

The lack of student loyalty to the university institutions where they take their education is evidenced by the results of the pre-survey that researchers have conducted on students of Muhammadiyah University, Serambi Mekkah University, and the BinaBangsa Teaching and Education College of Getsempena where the survey results prove the level of student loyalty to university is still low. One of the causes of low loyalty is the satisfaction of service users, whether it is students, student families, and alumni who are a measure of the success of educational institutions in managing their institutions and still prioritizing academic quality as 


\section{International Journal of Business Management and Economic Review}

Vol. 4, No. 02; 2021

ISSN: 2581-4664

service products that must be achieved.

Student satisfaction is a measure of feelings that arise after taking education at university institutions as well as the perceived service process provided by universities and compares with expected expectations. Many factors make students less satisfied with their universities. One of the important things that concern students is the competence of the lecturers who teach at theuniversity. The level of competence possessed by a lecturer has an impact on the quality of education for the courses that the lecturer takes care of. The process of teaching and learning quality is also a factor of student dissatisfaction because it is deemed not to meet the expectations of these students. Another thing that causes student dissatisfaction is the cost of education which is considered high but not commensurate with the facilities that each college has.

One of the predictor variables of student satisfaction is Perceived utilitarian value. Perceived utilitarian value comes from the perceived value which can be grouped based on the characteristics of the respondents, namely perceived hedonic value and perceived utilitarian value. Perceived utilitarian value is characterized as purchasing decisions that are rational, effective, and goal-oriented(Chiu, Wang, Fang, \& Huang, 2014).The emergence of utilitarian consumption behavior can be characterized by the existence of cost savings, namely cost savings is the main factor of the utilitarian concept, wherein in this case, someone will try to reduce the costs incurred to get certain products. In this research, the utilitarian segment is more emphasized because one of the points of selling is from affordable costs, both tuition fees and other costs, including by eliminating development costs which have always been the main source of income for similar private universities in Aceh and providing scholarships such as kip scholarships, achievements, hafiz scholarships, and other scholarships. With these scholarships, students do not need to think anymore about tuition fees and can make it easier for students to live their lives as students because there are several types of scholarships such as the kip scholarship which provide pocket money so that it makes students feel good about completing their studies.

The high or low level of perceived utilitarian value among students is strongly influenced by the quality of service and the image of the university. As it is known, in general, private universities in Aceh are the second choice when prospective students fail the public universities entrance examination. Therefore, the image of the university must always be the main concern of the managers of this private university. In addition to increasing the credibility level of the university in the form of accreditation level, promotion in the form of scholarship facilities as well as easy access to other useful facilities must be further improved to attract interest from prospective students to choose the college.

Based on the above phenomena, the authors researched to see the Role of Perceived Utilitarian Value and Student Satisfaction in Mediating the Influence of Service Quality (Servqual) and University Image on Loyalty in University in Banda Aceh. This research was conducted at private universities in Banda Aceh, namely Muhammadiyah Aceh University, SerambiMekkah University, and the BinaBangsa Teaching and Education College of Getsempena.

\section{LITERATURE STUDY Loyalty}

Customer loyalty in the world of education is closely related to student loyalty. Students who have high loyalty are university assets because they will provide positive recommendations 


\section{International Journal of Business Management and Economic Review}

Vol. 4, No. 02; 2021

ISSN: 2581-4664

and encourage friends, relatives, and other communities to use the educational services they have undertaken. Loyalty is a strongly held commitment to buy again or subscribe to certain products or services in the future(Kotler\& Keller, 2018). (Kotler \& Keller, 2018)also revealed that there are several approaches used in predicting consumer loyalty. Making loyalty into four parts/groups, namely: loyalists, potential loyalists, switchers, and variety seekers.

(Griffin, 2005)stated several advantages of having loyal customers, namely: 1) Reducing marketing costs; 2) Reducing transaction costs such as the cost of negotiating order contracts and others; 3) Reducing consumer turn off costs by replacing fewer customers; 4) Increase crossselling which will increase market share; 5) Word of the mount is more posit, and; 6) Reducing failure costs such as replacement costs. In this research, the measurement of loyalty uses the indicators disclosed by(Griffin, 2005)namely retention, repeat, referral, and reward, hereinafter referred to as 4'R to student loyalty

\section{Image}

Brand image plays an important role to improve the performance of any company or business. Brand Image is a tool that can positively change people's buying behavior.(Kotler\& Armstrong, 2017)defined image as "a set of beliefs, ideas, and impressions that a person has on an object".

In the future(Kotler\& Keller, 2018)also believed only with the image, the customer will be able to distinguish a market. Image is an impression obtained following one's understanding and knowledge of something. The same thing was also expressed by(Kristanti\& Farida, 2016)that image is the overall perception formed from objects based on the information and past experiences of consumers.(Putri, Farida, \& Dewi, 2014)divided this image attribute into 4 important groups, namely: evaluation criteria, shop characteristics, comparison process, and acceptable and unacceptable stores.

(Indriani \& Hendiarti, 2009)said that image is complex consumer perception of various important attributes that are different from a product or brand. In this research, image can be measured using indicators expressed by(Indriani\& Hendiarti, 2009)that is(1) friendly / unfriendly, (2) modern / outdated, (3) useful / not, (4) popular / unpopular, (5) gentle / harsh, (6) artificial / natural.

\section{Service Quality (Servqual)}

Service quality is a measure of how good the level of service provided is and following customer expectations(Tjiptono, 2017). The level of service quality cannot be assessed from the point of view of customer assessment. Therefore, in formulating service strategies and programs, companies must be oriented towards the interests of customers by paying attention to service quality components(Parasuraman, Zeithaml, \& Malhotra, 2005). To provide quality service that satisfies customers, we need to know the 5 dimensions of service quality(Kotler\& Keller, 2018). Five dimensions are used as a reference for measurements made by customers for services, namely tangibility, empathy, reliability, responsiveness, and assurance(Tjiptono, 2017).

\section{Student Satisfaction}

(Kotler \& Keller, 2018)revealed that customer satisfaction is the evaluation of the buyer where the alternatives chosen, at least, give the same or exceed customer expectations.(Basiya\& 


\section{International Journal of Business Management and Economic Review}

Vol. 4, No. 02; 2021

ISSN: 2581-4664

Rozak, 2012)stated that satisfaction is not always measured in money, but is based more on fulfilling feelings about what someone needs. If the level of satisfaction felt by customers is small, then there is a possibility that the customer will move to a competitor's product(Kozak, Bigné, \& Andreu, 2005).

(Sarjono, 2007)said student satisfaction is the comparison between the expectations students want about administrative services, lecturer competence supported by infrastructure, and leadership with what students feel after getting service. Based on(Sarjono, 2007)above, the dimensions of satisfaction measurement, teaching and learning process, facilities, curriculum, and lecturers were developed.

\section{Perceived Utilitarian Value}

Consumer behavior that is oriented towards utilitarian value will choose products efficiently based on rational reasons(Raza, Siddiquei, Awan, \& Bukhari, 2012). According to(Park \& Ha, 2016)utilitarian value is a consumer's assessment of the functional attributes of a product. Perceived value has also been seen as having cognitive and emotional dimensions. The most popular dimension in recent marketing literature, however, remains utilitarian and hedonic value(Asni, Nasir, Yunus, \& Darsono, 2018).

Utilitarian value is defined as the result of the conscious pursuit of desired consequences, which is task-oriented and rational(Kim, 2015).This is related to the visible benefits of products and services proven to play a role in achieving functional goals. Hedonic values, on the other hand, are indirect, intangible benefits that come from unique, symbolic functions and giving status, image, and emotional appeal(Seo, Choi, \& Lee, 2011). They are not related to any physical function of the product. Hedonic values are more subjective and personal, exemplified by values such as freedom, self-expression, and entertainment values(Wang, 2010). Utilitarian and hedonic value perceptions differ according to the subject, product, and time. Which dimension of perceived value is more important is debatable.

In this case, we can conclude that utilitarian value is to compare the sacrifices made by the customer with the benefits the customer receives when buying a product or service. (Seo et al., 2011)finding the purpose of customers assessing the utilitarian value of the product or service they buy is to assess the attributes, results, and efficiency of the product or service compared is to assess the attributes, results, and efficiency of the product or service compared to other competitors. They found that the purpose of customers assessing utilitarian values was to increase fashion leadership in purchasing clothes. In this research, Perceived Utilitarian Value can be measured using indicators as expressed by(Kang \& Park-Poaps, 2010; Park \& Ha, 2016)namely: 1. Students understand the importance of having a plan to enter university; 2. When students have entered university, students find talents that match my needs; 3 . Students will feel disappointed if the customer does not go to university at the university; 4. Students visiting the right campus must be decided appropriately.

\section{Conceptual Framework}

This research conceptual framework will explain the relationship between each variable on increased loyalty, which can be described as follow: 


\section{International Journal of Business Management and Economic Review}

Vol. 4, No. 02; 2021

ISSN: 2581-4664

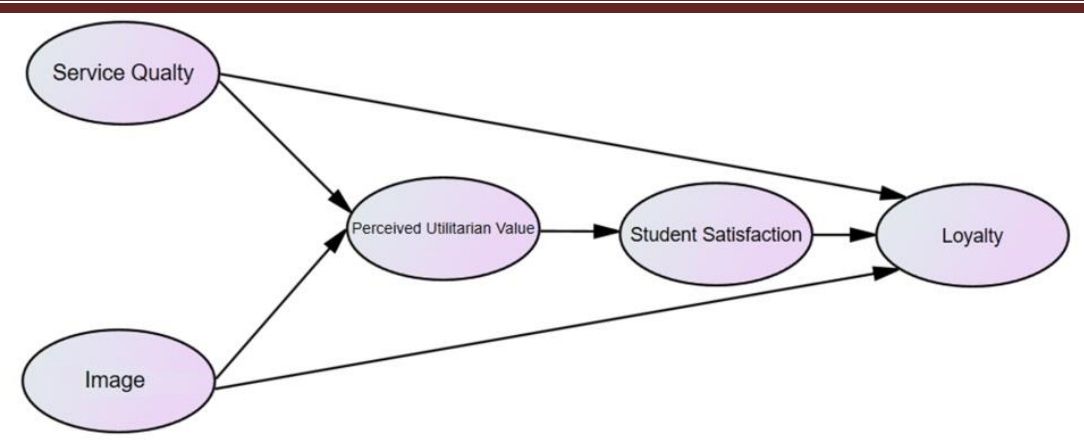

Figure 1.Conceptual Framework

Ha1: There is a Servqual Effect on Perceived Utilitarian Value at University in Banda Aceh.

Ha2: There is an Influence of University Image on Perceived Utilitarian Value at University in Banda Aceh.

Ha3: There is an Influence of Perceived Utilitarian Value on Customer Satisfaction at University in Banda Aceh.

Ha4: There is an Influence of University Image on Loyalty atUniversity in Banda Aceh.

Ha5: There is a Servqual Effect on Loyalty atUniversity in Banda Aceh.

Ha6: There is a Servqual Effect on Satisfaction through Perceived Utilitarian Value at University in Banda Aceh

Ha7: There is an Influence of University Image on Satisfaction through Perceived Utilitarian Valueat University in Banda Aceh

Ha8: There is a Servqual Effect on Loyalty through Perceived Utilitarian Value and Satisfactionat University in Banda Aceh

Ha9: There is an Influence of University Image on Loyalty through Perceived Utilitarian Value and Satisfactionat University in Banda Aceh

\section{RESEARCH METHOD}

The research was conducted at 3 (three) University Institutions in Banda Aceh namely Muhammadiyah University, SerambiMekkah University, and the Getsempena National Education and Teacher Training College, which are located in Banda Aceh city, Indonesia. Meanwhile, the variables of research was Perceived Utilitarian Value, Student Satisfaction, Servqual, University Image, and Student Loyalty. The population in this study were students who were studying at the universities with a population of 1916 people. (Malhotra, 2010)mentioned in quantitative research does not require the use of a sample that is too large. The number of research samples is allowed to be 5 to 10 times the number of indicators. In this research, the number of indicators was 34 , therefore the number of samples taken in this research was 170 people.

Data were collected using a questionnaire method, where the list of questions asked provides answers using a Likert scale. The analytical tool used in this research is Structural Equation Modeling (SEM) with the help of the Amos program. Hypothesis testing in this research was carried out in two stages, namely direct hypothesis testing and indirect hypothesis testing. Before testing the hypothesis, validity and reliability were tested, tested for confirmatory 


\section{International Journal of Business Management and Economic Review}

Vol. 4, No. 02; 2021

ISSN: 2581-4664

analysis, and evaluation of the goodness of fit. These tests were carried out to assess the feasibility of the measurement indicators. Furthermore, to perform indirect hypothesis testing used bootstrapping techniques, either for single mediation or sequence mediation. The hypothesis was said to have a significant effect on bootstrapping $t$ value $>1.960$ or $p$-value $<0.05$ at the 5\% significance level.Testing the mediating effect in this research used the concept of(Baron \& Kenny, 1986).

\section{RESULT AND DISCUSSION}

Direct Hypothesis

The structural model analysis explaining the effect test between variables is presented in the following path diagram:

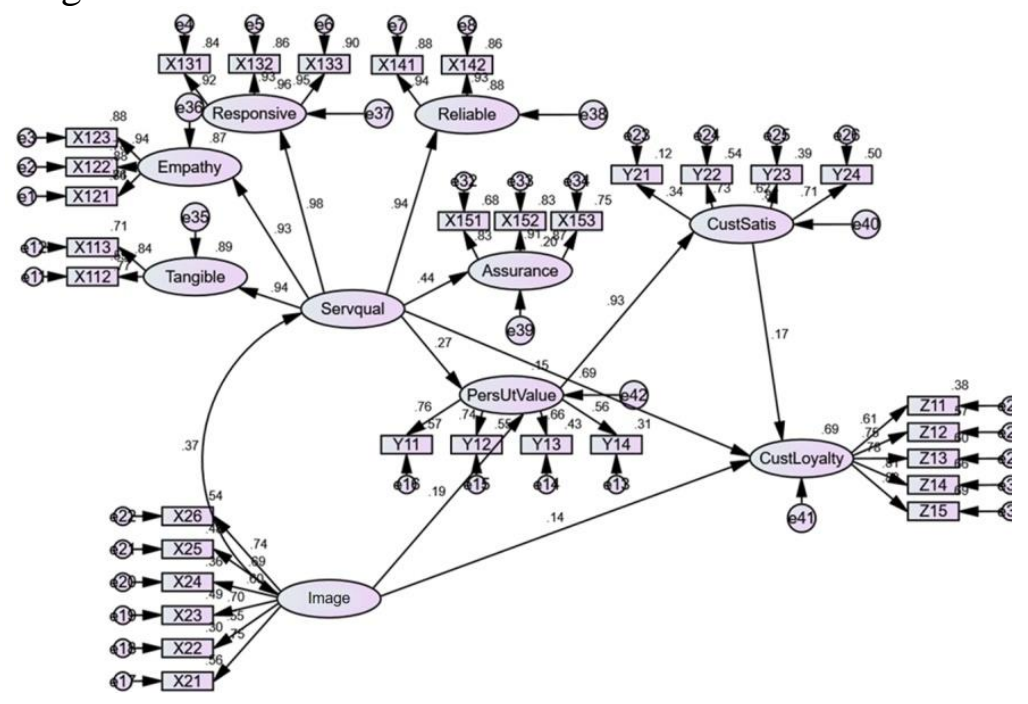

Figure 2.Test Results

The full model test results for testing the direct effect hypothesis after fulfilling the SEM assumptions are more clearly shown in the following table:

Table 1. Hypothesis Test Results

\begin{tabular}{|l|l|l|l|l|l|l|l|}
\hline Endogenous & & Exogenous & Estimate & S.E. & C.R. & P & Label \\
\hline PersUtValue & $<---$ & Servqual & .170 & .038 & 4.536 & $* * *$ & .275 \\
\hline PersUtValue & $<---$ & Imagery & .169 & .036 & 4.534 & $* * *$ & .191 \\
\hline CustSatis & $<---$ & PersUtValue & .465 & .081 & 5.652 & $* * *$ & .931 \\
\hline CustLoyalty & $<---$ & Imagery & .171 & .040 & 4.538 & $* * *$ & .136 \\
\hline CustLoyalty & $<---$ & Servqual & .605 & .088 & 6.871 & $* * *$ & .695 \\
\hline CustLoyalty & $<---$ & CustSatis & .466 & .082 & 5.653 & $* * *$ & .166 \\
\hline Reliable & $<---$ & Servqual & 1.279 & .094 & 13.589 & $* * *$ & .939 \\
\hline Responsive & $<---$ & Servqual & 1.244 & .089 & 13.910 & $* * *$ & .978 \\
\hline
\end{tabular}


International Journal of Business Management and Economic Review

Vol. 4, No. 02; 2021

ISSN: 2581-4664

\begin{tabular}{|l|l|l|l|l|l|l|l|}
\hline \hline Endogenous & & Exogenous & Estimate & S.E. & C.R. & P & Label \\
\hline Empathy & $<---$ & Servqual & .964 & .080 & 12.063 & $* * *$ & .931 \\
\hline Tangible & $<---$ & Servqual & 1.000 & & & & .941 \\
\hline Assurance & $<---$ & Servqual & .329 & .061 & 5.380 & $* * *$ & .444 \\
\hline
\end{tabular}

Source: Primary data, 2020 (processed)

By looking at the test results in table 2, the analysis can be explained as follows:

1. H1: The test of the effect of Servqual on Perceived Utilitarian Value produces a CR value of 4.536 and a probability of $* * *$. These two values prove that the results have met the requirements for acceptance of $\mathrm{H} 1$, namely the value of $\mathrm{CR}>1.96$ and the probability $<0.05$. So then it can be stated that the effect of Servqual on Perceived Utilitarian Value is significant. The magnitude of the Servqual Effect coefficient on Perceived Utilitarian Value is 0.275 so that the impact of the Servqual Effect on Perceived Utilitarian Value is $27.5 \%$

2. H2: The test of the influence of the Image of University on Perceived Utilitarian Value produces a CR value of 4.534 and a probability of $* * *$. These two values prove that the results have met the requirements in receiving $\mathrm{H} 2$, namely the value of $\mathrm{CR}>1.96$ and the probability $<0.05$. So then it can be stated that the influence of University Image on Perceived Utilitarian Value is significant. This means that if there is a need to increase Perceived Utilitarian Value, the Image of the University must also be improved. The magnitude of the Influence of University Image Influence is 0.191 or $19.1 \%$. So that the Influence of University Image can be used as a determinant factor to increase the perceived utilitarian value.

3. H3: The test of the effect of Perceived Utilitarian Value on Customer Satisfaction results in a CR value of 5,652 and a probability of ***. These two values prove that the results have met the requirements for acceptance of $\mathrm{H} 3$, namely the value of $\mathrm{CR}>1.96$ and the probability $<0.05$. So then it can be stated that the effect of perceived utilitarian value on customer satisfaction is significant. The magnitude of the influence coefficient of Perceived Utilitarian Value on Customer Satisfaction is 0.931, a relatively large coefficient that can encourage an increase in student satisfaction in this College.

4. H4: The test of the influence of the University Image Influence on Loyalty resulted in a CR value of 4.538 and a probability of $* * *$. These two values prove that the results have met the requirements for acceptance of $\mathrm{H} 4$, namely the value of $\mathrm{CR}>1.96$ and the probability $<0.05$. So then it can be stated that the Influence of University Image on Loyalty is significant. The coefficient of the Influence of University Image on Loyalty is 0.136 or $13.6 \%$. Thus the impact of the Influence of University Image on Loyalty can be done because of this significant influence.

5. H5: testing the effect of Servqual on Loyalty produces a CR value of 6,871 and a probability of $* * *$. These two values prove that the results have met the requirements for acceptance of $\mathrm{H} 5$, namely the value of CR> 1.96 and the probability $<0.05$. So then it can be stated that the effect of Servqual on Loyalty is significant. The coefficient of Servqual Effect on Loyalty is 0.695 or $69.5 \%$. Thus, the impact of Servqual Effect on Loyalty can be done because of this significant influence. 
International Journal of Business Management and Economic Review

Vol. 4, No. 02; 2021

ISSN: 2581-4664

\section{Indirect Hypothesis (Mediation)}

The results of testing the indirect hypothesis (mediation) are described below:

1. H6: Testing the Effect of Servqual on Satisfaction through Perceived Utilitarian Value is to find out the significant effect of mediation, it can be seen in the following figure:

2.

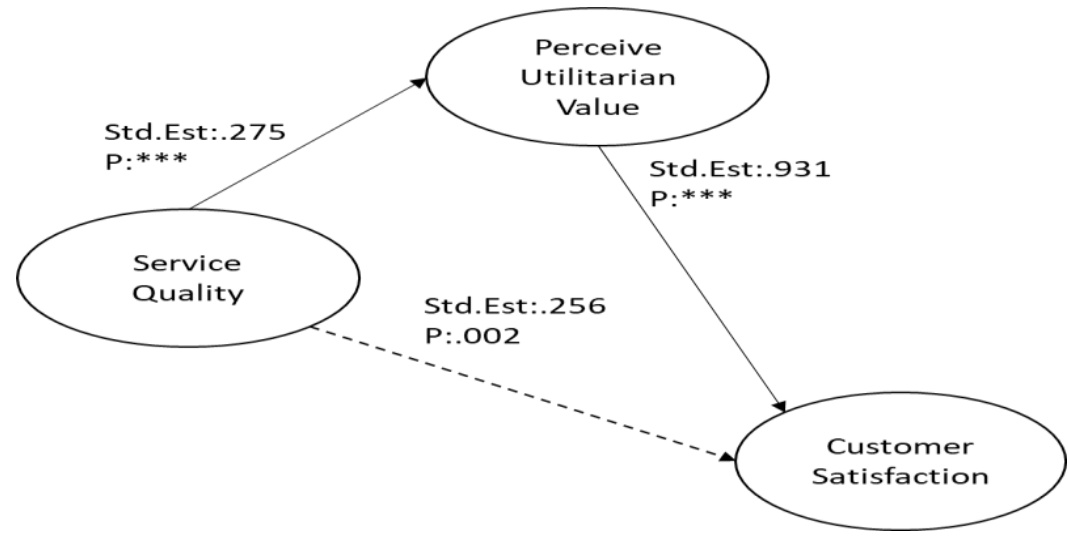

Figure 3.Result of Testing Hypothesis 6

Based on Figure 3 above, you can see the results of testing the Servqual Effect on Satisfaction through Perceived Utilitarian Value which results in a p-value of 0.002 . The pvalue obtained has met the requirements for Ha acceptance, which is less than 0.05 . Then it can be stated that the effect of Servqual on Satisfaction through Perceived Utilitarian Value is significant. The coefficient of Servqual Effect on Satisfaction through Perceived Utilitarian Value is 0.256 or $25.6 \%$. Thus, Perceived Utilitarian Value is said to play a role as a mediating variable because the effect of Servqual on satisfaction is significant if it is through this Perceived Utilitarian Value variable.

3. H7: testing the Influence of University Image on Satisfaction through Perceived Utilitarian Value as shown in the following figure.

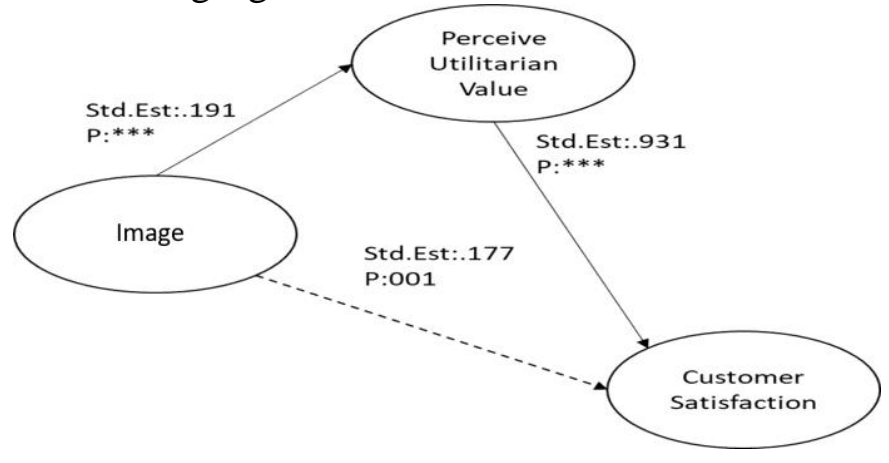

Figure 4.Result of Testing Hypothesis 7

Based on Figure 4 above, it can be seen the results of testing the Influence of University Image on Satisfaction through Perceived Utilitarian Value which produces a p-value of 
Vol. 4, No. 02; 2021

ISSN: 2581-4664

0.001. The P-value obtained has met the requirements for Ha acceptance, which is less than 0.05 . Then it is further stated that the Influence of University Image on Satisfaction through Perceived Utilitarian Value is significant. The magnitude of the coefficient of the Influence of University Image on Satisfaction through Perceived Utilitarian Value is 0.177 or $17.7 \%$. Thus, Perceived Utilitarian Value is said to play a role as a mediating variable because the influence of University Image on satisfaction is significant if through this Perceived Utilitarian Value variable.

4. H8: Testing the Effect of Servqual on Loyalty through Perceived Utilitarian Value and Satisfaction as shown in the following figure:

5.

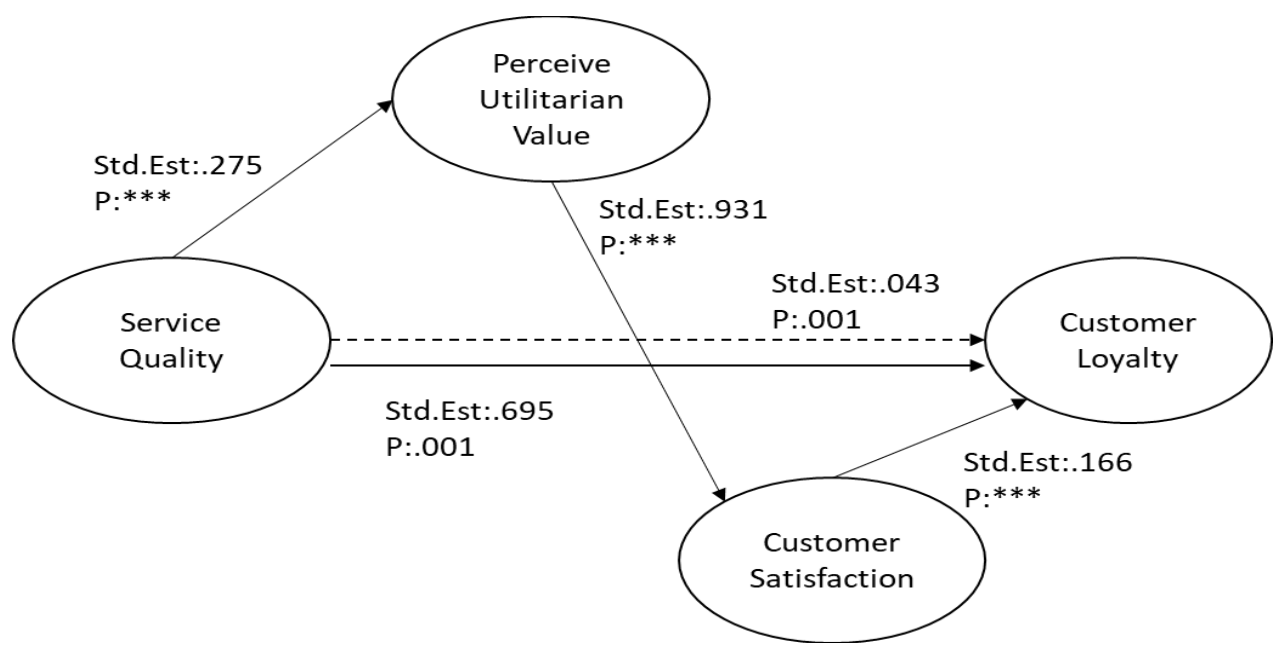

Figure 5.Result of Testing Hypothesis 8

Testing this hypothesis 8 is part of testing the sequence mediation hypothesis, which places the variable perceived utilitarian value and satisfaction as mediating variables, which are sequential, not parallel. Based on Figure 5 above, the estimated parameter value for testing the effect of Servqual Effect on Loyalty through Perceived Utilitarian Value and Satisfaction shows a p-value of 0.001 . The obtained value of P has met the requirements for Ha acceptance, which is less than 0.05 . Thus it can be stated that the Servqual Effect on Loyalty through Perceived Utilitarian Value and Satisfaction is significant. The magnitude of the Servqual Effect coefficient on Loyalty through Perceived Utilitarian Value and Satisfaction is 0.043 or $4.3 \%$. Thus Perceived Utilitarian Value and satisfaction are said to play a role as a mediating variable because the effect of Servqual on loyalty is significant if through the Perceived Utilitarian Value and satisfaction variables.

6. H9: Testing the Influence of University Image on Loyalty through Perceived Utilitarian Value and Satisfaction as shown in the following picture: 


\section{International Journal of Business Management and Economic Review}

Vol. 4, No. 02; 2021

ISSN: 2581-4664

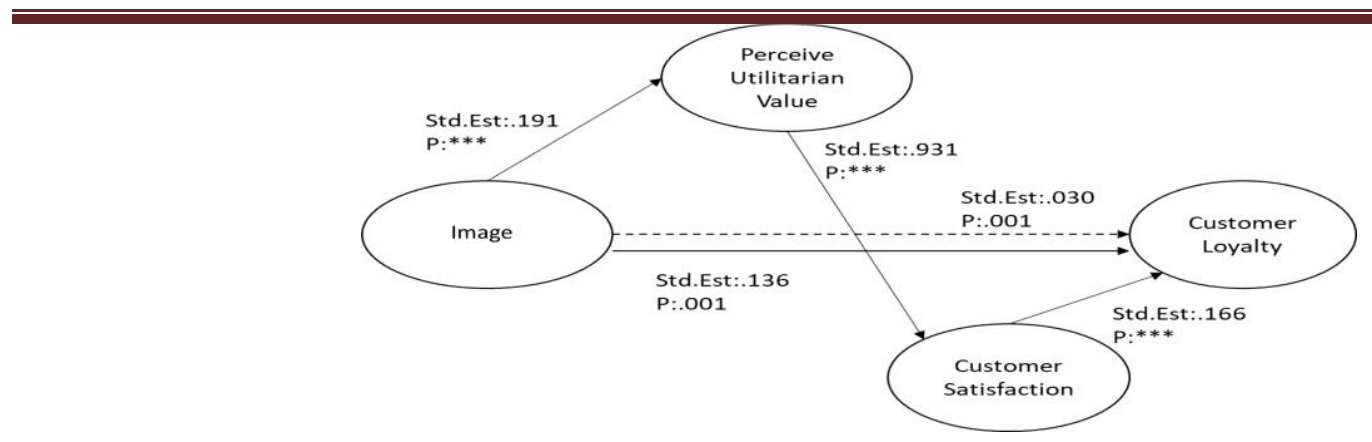

Figure 6.Result of Testing Hypothesis 9

Testing this hypothesis is part of testing the sequence mediation hypothesis, which places the variable of perceived utilitarian value and satisfaction as mediating variables, which are sequential, not parallel. Based on Figure 6 above, the estimated parameter value for testing the Influence of University Image on Loyalty through Perceived Utilitarian Value and Satisfaction shows a p-value of 0.001. The p-value obtained has met the requirements for acceptance of Ha, which is less than 0.05. Thus it can be stated that the Influence of University Image on Loyalty through Perceived Utilitarian Value and Satisfaction is significant. The magnitude of the coefficient of the Influence of University Image Influence on Loyalty through Perceived Utilitarian Value and Satisfaction is 0.030 or $3.0 \%$. Thus, Perceived Utilitarian Value and satisfaction are said to play a role as a mediating variable because the influence of university image on loyalty is significant if through the Perceived Utilitarian Value and satisfaction variables.

\section{CONCLUSION}

From the existing research findings, it can be seen that all of the hypotheses proven in this research were accepted. This means that student loyalty in private university institutions in Aceh does have interest in Servqual variables, University Image, Perceived Utilitarian Value, Customer Satisfaction, both of which affect loyalty directly or indirectly. From proving the direct hypothesis, of the 6 hypotheses tested, the largest direct effect coefficient is the effect of perceived utilitarian value on student satisfaction, namely $93.1 \%$. After that, it is followed by the influence of the Servqual Effect on Loyalty in University in Banda Aceh which has a coefficient value of $69.5 \%$, and the effect of Servqual on the perceived utilitarian value of $27.5 \%$.

While the direct influence that directly leads to student loyalty, of the 3 existing hypotheses, namely Servqual Effect on Loyalty in University in Banda Aceh, the Influence of University Image on Loyalty atUniversity in Banda Aceh, and the Effect of Student Satisfaction on Student Loyalty atUniversityin Banda Aceh, then the highest effect value is the Servqual Effect on Loyalty at University Institutions in Banda Aceh which has a coefficient value of $69.5 \%$, then followed by the effect of customer satisfaction on customer loyalty by $16.6 \%$ and finally the influence of PT's image on customers loyalty of $13.6 \%$.

For one-level direct effect, namely Servqual Effect on Satisfaction through Perceived Utilitarian Value and Influence of University Image on Satisfaction through Perceived Utilitarian Value, although both have a significant effect, the magnitude of Servqual Effect on Satisfaction through Perceived Utilitarian Value is greater than the Influence of University Image High on 


\section{International Journal of Business Management and Economic Review}

Vol. 4, No. 02; 2021

ISSN: 2581-4664

Satisfaction through Perceived Utilitarian Value, namely $25.6 \%$ versus $17.7 \%$. As for the twolevel indirect effect, namely, the effect of the Servqual Effect on Loyalty through Perceived Utilitarian Value and Satisfaction and the Influence of University Image on Loyalty through Perceived Utilitarian Value and Satisfaction, the one that has a greater influence magnitude is the Effect of Servqual Influence on Loyalty through Perceived Utilitarian Value and Satisfaction than the Influence of University Image on Loyalty through Perceived Utilitarian Value and Satisfaction, namely $4.3 \%$ versus $3.0 \%$.

The mediation role played by the variable perceived utilitarian value and student satisfaction in the effect of Servqual on student loyalty also has a positive and significant role, either together (sequentially) or separately. This proves once again that these 2 mediating variables, namely Perceived Utilitarian Value, and Customer Satisfaction, plus the two independent variables, namely Servqual and University Image, play a major role in increasing student loyalty in private universities in Banda Aceh. However, priority is still given to the increase in Servqual because the impact it causes, either directly or indirectly, plays a major role in increasing student loyalty in private universities, especially those located in Banda Aceh City and its surroundings.

\section{REFERENCES}

Aamir, A., Jehanzeb, K., Rasheed, A., \& Malik, M. J. (2012). Compensation Methods and Employees' Motivation (With Reference to Employees of National Commercial Bank Riyadh). International Journal of Human Resource Studies, 2(3), 221-230. https://doi.org/10.5296/ijhrs.v2i3.2474

Absar, M. M. N., Azim, M. T., Balasundaram, N., \& Akhter, S. (2010). Impact of Human Resources Practices on Job Satisfaction: Evidence from Manufacturing Firms in Bangladesh. Economic Sciences Series, LXII(2), 32-42. Retrieved from http://hdl.handle.net/123456789/578

Adam, F., \& Kamase, J. (2019). The Effect Competence And Motivation To Satisfaction And Performance. International Journal of Scientific \& Technology Research, 8(3), 132-140.

Ahmat, N. H. C., Arendt, S. W., \& Russell, D. W. (2019). Effects of minimum wage policy implementation: Compensation, work behaviors, and quality of life. International Journal of Hospitality Management, 229-238. https://doi.org/https://doi.org/10.1016/j.ijhm.2019.04.019

Akhtar, N., Aziz, S., Hussain, Z., Ali, S., \& Salman, M. (2014). Factors Affecting Employees Motivation in Banking Sector of Pakistan. Journal of Asian Business Strategy, 4(10), 125133.

Anita, J., Aziz, N., \& Yunus, M. (2019). The Effect Of Placement And Work Load On Work Motivation And Its Impact On Employee Work Performance At Labor And Population Mobility Agency Of Aceh Province, Indonesia. International Journal of Scientific \& Technology Research, 8(4), 225-229.

Asni, K., Nasir, Yunus, M., \& Darsono, N. (2018). Analysis on Internet Banking Services in Indonesia: Impact of Customer Value to Converting Intention. Proceedings of the 1st Aceh 


\section{International Journal of Business Management and Economic Review}

Vol. 4, No. 02; 2021

ISSN: 2581-4664

Global Conference (AGC 2018), 498-505. https://doi.org/https://doi.org/10.2991/agc18.2019 .73

Baron, R. M., \& Kenny, D. A. (1986). The moderator-mediator variable distinction in social psychological research: Conceptual, strategic, and statistical considerations. Journal of Personality and Social Psychology, 51(6), 1173-1182. https://doi.org/10.1037//00223514.51.6.1173

Basiya, \& Rozak, H. A. (2012). Kualitas dayatarik wisata, kepuasan dan niat kunjungan kembali wisatawan mancanegara di jawa tengah. Dinamika Kepariwisataan Jurnal Pengembangan Ilmu-Ilmu Kepariwisataan \& Perhotelan, 11(2), 1-12.

Chinyio, E., Suresh, S., \& Salisu, J. B. (2018). The impacts of monetary rewards on public sector employees in construction: A case of Jigawa state in Nigeria. Journal of Engineering, Design and Technology, 16(1), 125-142. https://doi.org/https://doi.org/10.1108/JEDT-122016-0098

Chiu, C.-M., Wang, E. T. G., Fang, Y.-H., \& Huang, H.-Y. (2014). Understanding customers' repeat purchase intentions in $\mathrm{B} 2 \mathrm{C}$ e-commerce: the roles of utilitarian value, hedonic value and perceived risk. Information Systems Journal, 24(1), 85-114. https://doi.org/10.1111/j.1365-2575.2012.00407.x

Darma, P. S., \& Supriyanto, A. S. (2017). the Effect of Compensation on Satisfaction and Employee Performance. Management and Economics Journal (MEC-J), 1(1), 69-78. https://doi.org/http://dx.doi.org/10.18860/mec-j.v1i1.4524

DiPietro, R. B., Kline, S. F., \& Nierop, T. (2014). Motivation and Satisfaction of Lodging Employees: An Exploratory Study of Aruba. Journal of Human Resources in Hospitality \& Tourism, 13(3), 253-276. https://doi.org/https://doi.org/10.1080/15332845.2014.866466

Ferdinand, A. (2014). Structural Equation Modeling dalam Riset Manajemen (5th ed.). Semarang: Badan Penerbit Universitas Diponegoro.

Griffin, J. (2005). Customer Loyalty: Menumbuhkan \& Mempertahankan Kesetiaan Pelanggan. Jakarta: Erlangga.

Indriani, F., \& Hendiarti, D. (2009). Studi Mengenai Efektifitas Iklan Terhadap Citra Merek Maskapai Garuda Indonesiaâ. Jurnal Sains Pemasaran Indonesia, 8(1), 83-106.

Kang, J., \& Park-Poaps, H. (2010). Hedonic and utilitarian shopping motivations of fashion leadership. Journal of Fashion Marketing and Management, 14(2), 312-328.

Kim, Y. (2015). Assessing the effects of perceived value (utilitarian and hedonic) in LCCs and FSCs: Evidence from South Korea. Journal of Air Transport Management, 49, 17-22. https://doi.org/https://doi.org/10.1016/j.jairtraman.2015.07.001

Kotler, P., \& Armstrong, G. (2017). Principles of Marketing (17th ed.). London: Pearson.

Kotler, P., \& Keller, K. L. (2018). Marketing Management, Global Edition (15th edition). Harlow, United Kingdom: Pearson.

Kozak, M., Bigné, E., \& Andreu, L. (2005). Satisfaction and Destination Loyalty: A Comparison 


\section{International Journal of Business Management and Economic Review}

Vol. 4, No. 02; 2021

ISSN: 2581-4664

Between Non-Repeat and Repeat Tourists. Journal of Quality Assurance in Hospitality \& Tourism, 5(1), 43-59. https://doi.org/https://doi.org/10.1300/J162v05n01_04

Kristanti, L. T., \& Farida, N. (2016). Pengaruh Citra Destinasi dan Fasilitas Wisata terhadap Niat Berperilaku Melalui Kepuasan Sebagai Variabel Intervening (Studi pada Pengunjung Museum Kereta Api Ambarawa). Jurnal Ilmu Administrasi Bisnis, 5(3), 117-126. Retrieved from https://ejournal3.undip.ac.id/index.php/jiab/article/view/12144

Mahdani, F., Hafasnuddin, \& Adam, M. (2017). Serta Implikasinya Pada Kinerja Karyawan ( Studi Pada Kanwil Pt . Bank Rakyat Indonesia (Persero) Tbk. Banda Aceh. Jurnal Magister Manajemen, 1(1), 1-15.

Malhotra, N. K. (2010). Riset Pemasaran: Pendekatan Terapan (4 Jilid 2). Jakarta: Index.

Marlina, D., Majid, M. S. A., \& Madjid, I. (2018). Mediated Effect of Motivation on the Influences of Emotional Intelligence and Competency on Employees' Performance Mediated Effect of Motivation on the Influences of Emotional Intelligence and Competency on Employees 'Performance. (August). https://doi.org/10.9790/487X-2008062735

Omolo, P. A. (2015). Effect of motivation on employee performance of commercial banks in Kenya: A case study of Kenya Commercial Bank in Migori County. International Journal of Human Resource Studies, 57-103. https://doi.org/https://doi.org/10.5296/ijhrs.v5i2.7504

Onukwube, H. N. (2012). Correlates of Job Satisfaction amongst Quantity Surveyors in Consulting Firms in Lagos, Nigeria. Australasian Journal of Construction Economics and Building, 12(2), 43-54. https://doi.org/10.5130/ajceb.v12i2.2460

Parasuraman, A. P., Zeithaml, V. A., \& Malhotra, A. (2005). E-S-Qual A Multiple-Item Scale For Assessing Electronic Servqual. Journal of Service Research, 7(3), 213-233. https://doi.org/10.1177/1094670504271156

Park, J., \& Ha, S. (2016). Co-creation of service recovery: Utilitarian and hedonic value and post-recovery responses. Journal of Retailing and Consumer Services, 28, 310-316. https://doi.org/https://doi.org/10.1016/j.jretconser.2015.01.003

Ping, R. A. (1995). A Parsimonious Estimating Technique for Interaction and Quadratic Latent Variables. Journal of Marketing Research, 32(3), 336-347. https://doi.org/10.2307/3151985

Putri, R. A., Farida, N., \& Dewi, R. S. (2014). Pengaruh Citra Destinasi, Fasilitas Wisata Dan Experiential Marketing Terhadap Loyalitas Melalui Kepuasan (Studi Pada Pengunjung Domestik Taman Wisata Candi Borobudur). Jurnal Ilmu Administrasi Bisnis, 4(1), 225235.

Raza, M. A., Siddiquei, A. N., Awan, H. M., \& Bukhari, K. (2012). Relationship Between Servqual, Perceived Value, Satisfaction And Revisit Intention In Hotel Industry. Interdisciplinary Journal Of Contemporary Research in Business, 4(8), 788-805.

Sarjono, Y. (2007). Faktor- Faktor Strategik Pelayanan Dosendan Dampaknya Terhadap Kepuasan Mahasiswa FKIP Universitas Muhamadiyah Surakarta Tahun Akademik 20052006. Varidika, 19(1), 66-74. Retrieved from http://hdl.handle.net/11617/677 
Vol. 4, No. 02; 2021

ISSN: 2581-4664

Sativa, O., Yunus, M., \& Majid, M. S. A. (2018). The Influence of Organizational Culture and Job Satisfaction of Workmotivation and Its Impact on the Performance of Employee. Jurnal Manajemen Inovasi, 9(1), 14-25.

Seo, K.-H., Choi, W.-S., \& Lee, S.-B. (2011). A Study on the Influence of the Selective Attributes of Home Meal Replacement on Perceived Utilitarian Value and Repurchase Intention: Focus on Consumers of Large Discount and Department Stores. Journal of the East Asian Society of Dietary Life, 21(6), 934-947.

Tjiptono, F. (2017). Strategi pemasaran (4th ed.). Jakarta: Andi.

Wang, E. S.-T. (2010). Internet usage purposes and gender differences in the effects of perceived utilitarian and hedonic value. Cyberpsychology \& Behavior: The Impact of the Internet, Multimedia and Virtual Reality on Behavior and Society, 13(2), 179-183. https://doi.org/10.1089/cyber.2009.0200 